\title{
Covid-19 and the evolution of the virus, which we can say at the end of June 2020.
}

\author{
"Nothing in Biology Makes Sense Except in the Light of Evolution" \\ Theodosius Dobzhansky $(1900$ - 1975)
}

Hélène Banoun, 24 June 2020

https://www.researchgate.net/publication/342501662 Covid-

19 and the evolution_of the virus_which_we can_say_at the end of June 2020?

channel=doi\&linkId $=5$ ef775a 792851 c52d600dd25\&showFulltext $=$ true 


\section{ABSTRACT}

How can we explain the temporal evolution of the pandemic?

The mutations in the viral RNA sequence observed in recent studies concern regions involved in the interaction of the virus with cells of the host immune system. It therefore seems to be confirmed that the emerging virus has adapted to the host immune system by modifying its transmissibility and virulence. The virus adapts by natural selection to the immune system of its host (the human population); it is the sum of these individual adaptations that produces the overall evolution of the virus during the epidemic. This hypothesis is consistent with the Theory of Evolution, which often helps to solve puzzles in biology.

\section{Introduction}

Many questions regarding the progression of Covid-19 since the emergence of the SARS-CoV2 virus remain unanswered.

Recent history should not be overlooked: the knowledge gained during the SARS epidemic of 2003-2004 and the biology of common coronaviruses could point to some clinical, epidemiological and therapeutic aspects of SARS-CoV-2 (Freymuth et al., 2009, Groneberg et al., 2004).

It seems that the explanatory hypotheses currently put forward do not refer to it enough.

As always in biology, the theory of evolution can enlighten us.

Did the virus remain stable during the epidemic with regard to its transmissibility and virulence?

\section{EVOLUTION OF THE VIRUS}

If we limit ourselves to the history of the epidemic on French soil, recent evidence shows that the virus arrived in October-November 2019. The first officially recorded cases in France ( Stoecklin et al., January 2020, ) date from mid-January, in Germany from the end of January (Rothe, March 2020), however a doctor from Alsace thinks that he saw dubious cases (a posteriori) in November 2019 (Schmitt, May 2020) with a very slow progression and an outbreak from the end of February. During the Military Games in Wuhan in mid-October, 2019 European athletes may have been infected and developed curious flu syndromes (RTL, May 2020, France TV, May 2020, Gouv.fr, October 2019).

In addition, a recent Harvard study (Nsoesie et al., 2020), shows a significant increase in hospital traffic and internet searches for symptoms associated with Covid from late summer 2019 in the Wuhan area. In particular, the gastrointestinal symptoms associated with Covid could explain why the beginning of the epidemic escaped the respiratory infection surveillance system. Moreover, it has been shown that children could transmit the virus by faecal route and not by respiratory excretion (Yi Xu et al., March 2020).

The molecular clock that gives an estimate of the date of emergence of the virus indicates an emergence between August and December 2019 (Van Dorp et al., Sept. 2020) but this mutational clock is not so accurate. For example, the speed of the clock (mutations/unit of time) may vary as the epidemic spreads. And the clock is calibrated based on the mutation rate of the available virus strains, not the initial strains. (Pierre Sonigo, 2020)

It is therefore possible that the emergence of the virus dates back to late summer 2019 in China and that it has penetrated as early as October 2019 (or earlier?) in the West. Why did the visible peak only occur from December to February in China and from the beginning of March to the end of April in France? The Marseille IHU, South of France, which began mass testing at the end of January, observed the first positive cases at the end of February 2020. The same phenomenon could be found throughout the world since the genomic diversity of the SARS-CoV-2 world population, summarized in many countries, indicates that the disease spread worldwide probably from the beginning of the 
pandemic (Van Dorp et al., 2020).

The authorities and the majority of scientists agree on the effect of the drastic health measures that would have interrupted the circulation of the virus. This was also the case in 2003-2004. If the virus was present in Europe as early as October 2019, it is difficult to see how lockdown from midMarch onwards could have had an effect. Similarly, if the virus emerged in China as early as the summer of 2019, it is hard to see how the lockdown imposed at the end of January 2020 could have changed the course of the virus. Sanitary measures are of course defended by those who promoted them (Imperial College, Flaxman et al., March 2020, June 2020, Okell et al., March 2020) and always by mathematical modelling (Acemoglou et al., May 2020), the confrontation of the models with the reality of what happened seems to be problematic.

Moreover, numerous studies have been published showing that the strict lockdown of the entire population is not responsible for the decline of the epidemic: not to be confused with the isolation of the sick and the targeted protection of vulnerable people. These studies look at the effect of confinement from different angles, but they all point in the same direction. They are based, contrary to the models already mentioned, on analyses of data collected during the epidemic.

(Toussaint, 13 June 2020; Zelmat, 26 May 2020; Pech de Laclause et al ; Andolfatto and Labbé, 5 June 2020 ; Aslangul, 5 June 2020 ; Andolfatto and Labbé, 22 June 2020 ; Le Bourg et al; Gøtzsche; Wittkowski; Raude, April 2020; Nordmann, 2 May 2020; Meunier T.A.J. 2020; Crowe, 20 June 2020).

Explanations based on mathematical modelling of R0 and kappa (dispersion factor) seem insufficient to explain the epidemic curve ( Korsia-Meffre, June 2020).

An analysis of the curves of the late-stage epidemic shows the worldwide trend towards the benignity of the virus. There has been a sustained increase in new cases with a steady decline in severe cases and deaths. It is important to base oneself on the speed of the curves and not on the raw figures of cases or deaths (even in countries where reliable statistics are available, large discrepancies exist depending on the counting methods, for example in France on the weekly "Point épidémiologique hebdomadaire Santé Publique" of 18 June 2020, "11,016 death certificates were found to contain a mention of COVID-19 among the medical causes of death listed" and above "Between March 1 and June 16, 2020, 29,547 deaths of COVID-19 patients were reported to Santé publique France" (Santé Publique France, June 2020).

The evolution of the viral population in relation to the immune system of its host (the world population) could explain the "accelerations" and "decelerations" of the virus as evoked by Pierre Sonigo for the evolution of AIDS in a given individual ("Ni Dieu, ni gène", Ed Seuil, 2005).

It is accepted that the virus emerges as a result of recombinations that allow it to cross the famous "species barrier"; then deletions and mutations allow it to continually adapt to its host (Freymuth et al;, 2009).

A small vocabulary is necessary: the word virus refers to the viral population which gathers all virions (virus individuals).

Each time a new human individual is infected, a more or less important quantity of virions is produced according to the immediate innate immune response. This population of virions adapts by natural selection to the immune system of its host (in particular to the "receptors" of the virus); it is the sum of these individual adaptations that produces the overall evolution of the virus during the epidemic. The term "immunity" refers both to a process and an outcome; there is an evolutionary race between the viral population and immunity as a process produced by the human population. This assumption is consistent with the Theory of Evolution, which often solves puzzles in biology. It is 
consistent with JJ Kupiec's theses on the apparent order at the macroscopic scale that results from disorder at the molecular level. ("Et si le vivant était anarchique?", Ed. Les liens qui libèrent, 2019)

The following observations may support this hypothesis

Already in April 2020, modelling based on the evolution of the viral population in relation to the host immune system had been attempted. (Dimaschko and Podolsky, April 2020). This study models the epidemic in different countries, taking into account the evolution of the viral population towards less transmissibility and less virulence; the models are compared with actual curves in the world, in Russia, USA, South Korea, Germany, Spain, Italy. The comparison confirms that the epidemic develops according to the evolution of the virus and not to the group immunity acquired by the human population. The natural evolution of the viral population in contact with its host reflects the observed curves.

The study of the evolution of the SARS-CoV sequence in 2003-2004 had already suggested that mutations that appeared during the epidemic could explain its history (Drösten, 2018) (mutation in the ORF8 region). Already in 2003 the first SARS had evolved rapidly at the ORF8 level, with a deletion causing less active replication and attenuation of virulence. "ORF8 is one of the most relevant genes in the study of potential viral adaptation to humans. A deletion of 29 nucleotides within ORF8 has occurred in all strains involved in the mid- and late-phase human epidemic. Proteins encoded by the ORF8 of SARS facilitate viral replication regardless of the host cell system. Reduced initial fitness is a condition that can be expected in early stage zoonotic epidemics, when the virus is not yet adapted to the new host environment."

In 2020, for SARS-CoV-2, several studies confirm this tendency of the virus to evolve towards less virulence.

As early as April 2020 Van Dorp (Van Dorp et al.), show that mutations accumulated independently (by evolutionary convergence) during the temporal evolution of the epidemic, they concerned the ORF1 region (which codes for NSP6, a non-structural protein) and which contains homoplasia (mutations that appear independently) important for adaptation to humans. This region covers a peptide presumed to react with CD4+ and CD8+ cells of adaptive cellular immunity. Although the immune response to SARS-CoV-2 is still poorly understood, the key roles of CD4 T cells, which activate B cells to produce antibodies, and cytotoxic CD8 T cells, which kill virus-infected cells, are known to be important in mediating clearance in respiratory viral infections. Like most (but not all) pathogens capable of causing a pandemic-scale outbreak, SARS-CoV-2 is likely to be of zoonotic origin. This means that SARS-CoV-2 may not be adapted to its new human host, which would explain the accumulation of mutations in the area responsible for this adaptation.

Also in April 2020, a team in Arizona (Holland et al., May 2020 ) also found a deletion in the ORF7 region from the sequences deciphered at the beginning of the outbreak in Wuhan. This deletion was recovered from a pool of 382 sequences collected in late phase in Arizona. It concerns 81 nucleotides and 27 corresponding amino-acids in a region that could be important for the adaptation of the virus to humans (because it is close to the ORF8 region identified in 2003).

Again in April 2020, a team from Singapore found a deletion in the late phase of the epidemic in the ORF8 region (this deletion was found at the end of February 2020 in Singapore, which corresponds to the late phase for Asia) (Su et al., March 2020). The authors also suggest that the major deletion revealed in this study could lead to an attenuated SARS-CoV-2 phenotype.

In June 2020, an Italian publication was announced by Prof. Massimo Clementi from Milan (Il Giornale, June 2020), who also reportedly found mutations potentially responsible for the attenuation of the virus during the epidemic in Italy. 
The mutations in the viral RNA sequence observed in these recent studies therefore concern regions involved in the interaction of the virus with cells of the host immune system. It thus seems to be confirmed that the emerging virus has adapted to the host immune system by modifying its transmissibility and virulence. This adaptation is thought to have occurred in fits and starts in the Wuhan region, after a phase of relative latency characterized by an epidemic of ill-defined syndromes in the summer of 2019 until the SARS outbreak in December. Similarly, when it arrived in the West in autumn 2019, the virus would have made its way through a genetically different population and would have finally flared up in March 2020 after having acquired mutations favouring its transmissibility and respiratory virulence. All this can only remain speculative since the mutations between the time of its supposed emergence and the start of the outbreak can never be studied, due to the lack of genomic sequences collected during the "latency" period.

This is also observed for the influenza virus which is adapted to humans and is not an emerging virus. During the winter of 2018-2019, in Canada, antigenic drift from the H1N1 subtype to the H3N2 subtype was observed between January and March 2019. This drift allows the virus to reach different populations depending on their age; in fact, it has been demonstrated that there is an antigenic imprinting phenomenon for influenza: individuals are more or less sensitive to one subtype or another depending on their age and on the subtype encountered for the first time in their lives (Gagnon et al.). Here again, this can be interpreted as an evolution of the virus in relation to the host immune system, the virus returning this time to a subtype that has already appeared previously, contrary to the case of SARS-CoV-2, an emerging virus.

\section{CONCLUSION}

It is not impossible that all common cold coronaviruses, when they jumped from animals to humans (they are all originally responsible for zoonoses), began their evolutionary course like SARSCoV-2 with a pandemic like Covid-19.

But at the time, the means of investigation in virology and molecular biology did not exist and were not identified.

Other cold coronaviruses are known to be common viruses; it is not impossible that SARS-Cov2 could become a common coronavirus after mutations.

As explained by Prof. Didier Sicard (Sicard, June 2020), further pandemics of this type are to be expected due to the abundance of zoonotic viruses circulating in close proximity to humans as a result of Asian dietary habits and the profound changes in the ecology of the planet produced by human activity.

Preparation for this would require, at a minimum, effective monitoring of the circulation of respiratory viruses in all countries. In France, is the current surveillance system for influenza syndromes in ambulatory medicine "Sentinelles" and "GrippeNet" sufficient to face such challenges? One can doubt it when one reads that between June 1st and June 7th, 2020, this network has analyzed only 128 suspicious samples of Covid for the whole country (Point épidémiologique hebdomadaire Santé Publique France, June 11th, 2020), and 152 samples at the beginning of March, thus well before the deployment of specific tests for Covid but already in full outbreak (Bulletin hebdomadaire grippe Santé Publique France, March 11th, 2020).

Hélène Banoun, https://www.researchgate.net/profile/Helene Banoun

PhD, Pharmacist biologist

Former INSERM Research Officer

Former Intern at the Paris Hospitals (APHP)

helene.banoun@orange.fr

Covid-19, virus evolution 


\section{REFERENCES}

Acemoglou et al., https://www.nber.org/papers/w27102 mai 2020

Andolfatto et Labbé, 5 juin 2020 https://www.revuepolitique.fr/covid-19-premier-bilan-de-lepidemie/

Andolfatto et Labbé, 22 juin 2020 https://www.revuepolitique.fr/covid-19-une-defaite-francaise/

Aslangul, 5 juin 2020 https://www.contrepoints.org/2020/06/05/372827-deconfinement-il-faut-allerplus-vite?utm source $=$ Newsletter+Contrepoints\&utm campaign $=\mathrm{d} 8 \mathrm{ee} 4 \mathrm{ba} 827$ -

Newsletter_auto Mailchimp\&utm medium $=$ email\&utm term $=0$ 865f2d $37 \mathrm{~b} 0$-d $8 \mathrm{ee} 4 \mathrm{ba} 827$ -

$113559185 \& \mathrm{mc}$ cid $=\mathrm{d} 8 \mathrm{ee} 4 \mathrm{ba} 827 \& \mathrm{mc}$ eid $=\mathrm{e} 163844922$

Bulletin hebdomadaire grippe Santé Publique France, March 11th, 2020

https://www.santepubliquefrance.fr/content/download/235884/2528455

Dimaschko et Podolsky, avril 2020,

https://www.medrxiv.org/content/10.1101/2020.04.09.20059782v2

Drosten, 2018 https://www.nature.com/articles/s41598-018-33487-8

Flaxman et al., mars 2020, DOI: https://doi.org/10.25561/77731

Flaxman et al., juin 2020, https://www.nature.com/articles/s41586-020-2405-7 reference.pdf

France TV, mai 2020 https://sport.francetvinfo.fr/omnisport/des-sportifs-francais-contamines-par-lecovid-19-des-octobre-aux-jeux-militaires-de-wuhan?xtor=SEC-1039-

\%5BFil_rouge Article Des_sportifs francais contamines_par_le Covid 19 des octobre aux_Je ux militaires de Wuhan \%5D-\%5B2085551\%5D-\%5B $\% 5 \mathrm{D}-\% 5 \mathrm{~B} \% 5 \mathrm{D}-\% 5 \mathrm{~B} \% 5 \mathrm{D}-\% 5 \mathrm{~B} \% 5 \mathrm{D}$

Freymuth et al., 2009 https://www.ncbi.nlm.nih.gov/pmc/articles/PMC7125620/

Gagnon et al., https://academic.oup.com/cid/advance-articleabstract/doi/10.1093/cid/ciaa075/5716254?redirectedFrom=fulltext Gøtzsche ://www.deadlymedicines.dk/coronavirus-pandemien-kan-vi-gore-det-bedre/

Gouv.fr, octobre 2019, https://www.defense.gouv.fr/terre/actu-terre/jeux-mondiaux-militaire-d-ete-dewuhan)

Groneberg et al., 2004 https://www.ncbi.nlm.nih.gov/pmc/articles/PMC548145/pdf/1465-9921-6-8.pd $\underline{\mathrm{f}}$

Holland et al., mai 2020, https://jvi.asm.org/content/early/2020/04/30/JVI.00711-20

Il Giornale, juin 2020, https://www.ilgiornale.it/news/cronache/cosa-sta-succedendo-davvero-virus$\underline{1867430 . h t m l}$

Korsia-Meffre, juin 2020

https://www.vidal.fr/actualites/25061/covid 19 la seule chose qui compte c est l endroit ou s_qu

Covid-19, virus evolution 
elle tombe ou comment_eviter une eventuelle deuxieme vaguel

Le Bourg et al., 2020, ,https://hal.archives-ouvertes.fr/hal-02560574/document

Nordmann, 2 mai 2020 https://b.marfeel.com/amp/www.contrepoints.org/2020/05/02/370212-confinesmais-non-testes-la-potion-toxique-des-gaulois

Nsoesie et al., 2020

https://dash.harvard.edu/bitstream/handle/1/42669767/Satellite_Images_Baidu_COVID19 manuscript DASH.pdf? sequence $=3$ \&isAllowed $=y$ )

Okell et al., juin 2020 https://www.thelancet.com/pdfs/journals/lancet/PIIS0140-6736(20)31357-X.pdf

Pech de Laclause et al. https://ssrn.com/abstract=3598484

Pierre Sonigo, 2020 : https://www.linkedin.com/feed/update/urn:li:activity:6680032815687503872/? commentUrn=urn\%3Ali\%3Acomment $\% 3 \mathrm{~A}$ (ugcPost \%3A6679672475342766080\%2C6680032758347173888

Point épidémiologique hebdomadaire Santé Publique France, June 11th, 2020 https://www.santepubliquefrance.fr/maladies-et-traumatismes/maladies-et-infectionsrespiratoires/infection-a-coronavirus/documents/bulletin-national/covid-19-point-epidemiologique-du$\underline{18-j u i n-2020}$

Raude, avril 2020 https://www.francebleu.fr/infos/faits-divers-justice/la-quarantaine-en-france-unmodele-autoritaire-selon-un-chercheur-1587018502

Rothe, mars 2020 https://www.nejm.org/doi/full/10.1056/NEJMc2001468

RTL, mai 2020 http://www.rtl.fr/actu/international/les-infos-de-12h30-coronavirus-des-temoignagestroublants-sur-1-origine-du-covid-19-7800483407

Santé Publique France, juin 2020 https://www.santepubliquefrance.fr/maladies-ettraumatismes/maladies-et-infections-respiratoires/infection-a-coronavirus/documents/bulletinnational/covid-19-point-epidemiologique-du-18-juin-2020

Sicard, juin 2020 https://www.publicsenat.fr/article/debat/pr-didier-sicard-le-virus-s-arretera-avant-larrivee-du-vaccin-183309

Stoecklin et al., janvier 2020, https://www.eurosurveillance.org/content/10.2807/1560-7917.ES.2020.25.6.2000094

Su et al., mars 2020 https://www.biorxiv.org/content/10.1101/2020.03.11.987222v1

Toussaint 13juin 2020, https://www.jim.fr/medecin/jimplus/tribune/edocs/_debut_avril_des_choix_differents_auraient_pu_etre_adoptes_face_a_lepidemie_.entretien_avec 
le_pr jean_francois toussaint 183339/document_edito.phtml

Van Dorp et al., sept 2020, https://www.sciencedirect.com/science/article/pii/S1567134820301829

Wittkowski; https://www.spiked-online.com/2020/05/15/we-could-open-up-again-and-forget-thewhole-thing/

Yi Xu et al., mars 2020, https://www.nature.com/articles/s41591-020-0817-4

Zelmat, 26 mai 2020,https://papers.ssrn.com/sol3/papers.cfm?abstract $\mathrm{id}=3600511$ 